prof. dr hab. inż. Mieczysław SZUSTAKOWSKI ${ }^{1}$

ppłk dr inż. Marek ŻYCZKOWSKI ${ }^{1,2}$

mgr inż. Mateusz KAROL ${ }^{1}$

dr inż. Mariusz KASTEK ${ }^{1}$

ppłk dr inż. Rafał DULSKI ${ }^{1}$

mjr dr inż. Jarosław BARELA ${ }^{1}$

mgr inż. Piotr MARKOWSKI ${ }^{1}$

dr inż. Marcin KOWALSKI ${ }^{1}$

Przyjęty/Accepted/Принята: 29.08.2013;

Zrecenzowany/Reviewed/Рецензирована: 18.07.2014;

Opublikowany/Published/Опубликована: 31.12 .2014 ;

\title{
DALEKOZASIEGOWA KAMERA DO MONITOROWANIA OBIEKTÓW INFRASTRUKTURY KRYTYCZNEJ TESTY ZASIĘGOWE ${ }^{3,4}$
}

\author{
Range Capability Testing of Long Range Surveillance Cameras Used \\ for Protection of Key Installations
}

\author{
Камера с большой дальностью видеонаблюдения для мониторинга \\ объектов критической инфраструктуры. Исследования дальности
}

\begin{abstract}
Abstrakt
Cel badań: Głównym celem badań było wyznaczenie i zweryfikowanie efektywnego zasięgu działania systemu kamerowego LongView 2 zarówno w warunkach laboratoryjnych, jak i rzeczywistych. W szczególności dla badanego zestawu kamerowego określenie odległości, na której możliwa jest identyfikacja, rozpoznanie i detekcja obserwowanego celu.

Wprowadzenie: Kamery wizyjne, niskiego poziomu oświetlenia oraz przeciwmgielne mają różną zdolność do rejestrowania informacji zewnętrznych, połączenie ich cech może znacznie poprawić zdolność wykrywania intruzów, sytuacji awaryjnych lub zagrażających bezpieczeństwu monitorowanego obiektu. Specjalnie zaprojektowany, na potrzeby nadzoru, wielosensorowy układ detekcyjny kamery tego typu pozwala na obserwację celów na dużym dystansie oraz ich śledzenie za pomocą systemu uchylno-obrotowego z zastosowaniem zoomu optycznego. Dzięki zastosowaniu układu wielosensorowego możliwe jest obserwowanie i śledzenie celu w trudnych warunkach na dużych odległościach, dodatkowo wszystkie elementy systemu zintegrowane są w jednej obudowie, oferując kompaktowość przedstawionego rozwiązania. Dzięki zwartej budowie oraz zastosowaniu wielosensorowego systemu obserwacji opisywany zestaw kamerowy z powodzeniem może być stosowany przez różne służby bezpieczeństwa.

Metodyka badań: Artykuł opisuje przeprowadzone badania w celu określenia rzeczywistych parametrów na potrzeby ich ustandaryzowania, ze szczególnym naciskiem na zakres wykrycia, rozpoznania i identyfikacji człowieka. W artykule przedstawione zostały wykorzystane urządzenia pomiarowe, procedury oraz wyniki. Testy przeprowadzone były zgodnie z procedurą pomiarową akredytowanego Laboratorium Badawczego Instytutu Optoelektroniki WAT „Pomiary parametrów urządzeń termowizyjnych”. Wykorzystane metody pomiarowe pozwoliły na określenie parametrów takich jak: minimalna rozróżnialna różnica temperatur (MRTD), minimalny rozróżnialny kontrast (MRC) oraz funkcja przenoszenia modulacji (MTF). Przeprowadzone badania poligonowe miały na celu weryfikację działania i użyteczności testowanych kamer w rzeczywistych warunkach pracy oraz porównanie wartości parametrów zmierzonych podczas testów laboratoryjnych z obiektywną oceną operatora kamery.
\end{abstract}

\footnotetext{
${ }^{1}$ Wojskowa Akademia Techniczna im. Jarosława Dąbrowskiego; gen. Sylwestra Kaliskiego 2, Warszawa / Military University of Technology, Warsaw, Poland;

${ }^{2}$ mzyczkowski@wat.edu.pl;

${ }^{3}$ Każdy ze współautorów wniósł równy wkład merytoryczny w powstanie artykułu (po 12,5\%) / The authors contributed equally to the article;

${ }^{4}$ Artykuł został wyróżniony przez Komitet Redakcyjny / The article was recognised by the Editorial Committee;
} 
Wyniki: Przeprowadzone badania laboratoryjne i poligonowe pozwoliły na określenie zasięgów skutecznego działania kamer systemu LongView 2 do zastosowań w systemach ochrony obiektów rozległych.

Wnioski: Przeprowadzone badania i testy potwierdziły skuteczność działania systemu kamer LongView 2 zarówno przy zastosowaniach do identyfikacji zagrożeń, jak i dalekozasięgowej obserwacji obiektów morskich i lądowych.

Słowa kluczowe: kamera dalekozasięgowa, system obserwacyjny, test zasięgowy, kamera przeciwmgielna Typ artykułu: oryginalny artykuł naukowy

\begin{abstract}
Aim: The main purpose of this research was to determine and verify the effective range of Long View 2 camera systems in laboratory and practical conditions. Particularly, the authors endeavoured to determine the distance at which the tested camera could identify, recognize and detect an observed target.

Introduction: Low light vision and fog video cameras have different abilities to record external information. Therefore, the linking of their individual features may significantly improve the ability to detect intruders, emergency incidents or situations which endanger the safety of a target under surveillance. Specially designed for surveillance, multi-sensor detection camera systems facilitate observation at a long distance and tracking of targets with the aid of a pan-tilt mechanism incorporating an optical zoom. All system components are integrated in a single compact housing. The compact design and multi-sensor components allow for the equipment to be used successfully by various security services.

Methodology: This article describes a research process used to determine practical application parameter standards, with a special focus on the range for detection, recognition and identification of humans. The article identifies measuring equipment used, procedures and results. Tests were carried out in accordance with established procedures "Parameter measurements of infrared devices", established by the accredited Testing Laboratory of the Institute of Optoelectronics, Military University of Technology (MUT). The process applied in the research allowed for the determination of parameters such as; the minimum resolvable temperature difference (MRTD), the minimum resolvable contrast (MRC) and the modulation transfer function (MTF). Field tests were performed to verify the capability and usability of cameras in working conditions. Additionally, results obtained during laboratory tests were compared with an objective assessment by the camera operator.

Results: Laboratory research and field tests facilitated the determination of an effective range for the operation of the Long View 2 camera system, intended for use in security systems covering a large expanse.

Conclusions: Conducted research and tests have confirmed the effectiveness of the Long View 2 camera system for use in identification of threats and long-range observation of offshore and onshore targets.
\end{abstract}

Keywords: long range surveillance camera, observation systems, range test, anti-fog camera

Type of article: original scientific article

\title{
Аннотация
}

Цель исследования: Основная цель исследования заключалась в определении и проверке эффективной дальности работы видеокамеры системы LongView 2 как в лабораторных, так и в реальных условиях. В частности определение величины расстояния для исследованного комплекта камер, при которой можно идентифицировать, распознать и обнаружить наблюдаемую цель.

Введение: Видеокамеры для использования в режиме низкого света, а также противотуманные камеры характеризуются разной способностью регистрации внешней информации, а сочетание их функций может значительно улучшить способность обнаруживать злоумышленников или чрезвычайные ситуации, угрожающие безопасности контролируемого объекта.

Специально разработанная для мониторинга, многосенсорная детекторная система камеры данного типа позволяет наблюдать цели на большом расстоянии и отслеживать их с помощью исклонно-поворотной системы с оптическим зумом. Благодаря применению многосенсорной системы можно наблюдать и следить за объектом наблюдения в сложных условиях и на больших расстояниях. Кроме того, все элементы системы интегрированы в одном корпусе, тем самым обеспечивая совокупность представленного решения. Благодаря компактной конструкции и применению многосенсорной системы наблюдения, описанный состав видеокамер может быть успешно использован различными службами безопасности.

Методология исследований: Статья описывает исследования, проведенные для определения фактических параметров с целью их стандартизации, особенно учитывая расстояние, при котором можно обнаружить, распознать и идентифицировать человека. В статье представлены использованные измерительные приборы, процедуры и результаты. Испытания проводились в соответствии с процедурой измерения аккредитованной испытательной лаборатории Института оптоэлектроники WAT „Измерения параметров тепловизионных устройств”. Использованные измерительные методы позволили определить такие параметры, как: минимальная отличимая разница температур (MRTD), минимальный заметный контраст (MRC) и функция передачи модуляции (MTF). Исследования в условиях полигона проводили для проверки действия и использования испытываемых камер в реальных условиях работы, а также сравнения значений параметров, полученных в ходе лабораторных испытаний с объективной оценкой оператора камеры.

Результаты: Проведенные лабораторные и полигонные исследования позволили определить диапазоны эффективного действия камеры LongView 2 для применения в системах защиты обширных объектов.

Выводы: Исследования и испытания подтвердили эффективность действия системы камер LongView 2 как при идентификации угроз, так и при наблюдении морских и сухопутных объектов на большом расстоянии.

Ключевые слова: камера с большой дальностью видеонаблюдения, система наблюдения, исследования дальности, противотуманная камера

Вид статьи: оригинальная научная статья 


\section{Wprowadzenie}

Systemy obserwacyjne są istotnym elementem systemu bezpieczeństwa [1-3]. Znajdują się na wyposażeniu sprzętu wojskowego, policyjnego, straży granicznej i służb ratowniczych. Stanowią także niezbędny element systemu ochrony obiektów infrastruktury krytycznej. Pozwalają na prowadzenie w tych obiektach skutecznej obserwacji terenu w warunkach nocnych.

Systemy te mogą być konfigurowane w różnej postaci. Najczęściej same systemy ochrony posiadają kilkanaście lub nawet kilkadziesiąt urządzeń obserwacyjnych. Ponieważ koszt zakupu urządzeń obserwacyjnych jest znaczny, dlatego bardzo istotnym zagadnieniem jest optymalizacja doboru takich elementów. Optymalizacja nie polega jednak jedynie na kupowaniu najtańszych elementów wyposażenia. Polega ona na takim dobraniu elementów składowych systemu, aby ich zastosowanie spełniało wymagania aplikacyjne $\mathrm{z}$ uwzględnieniem szeroko rozumianego zagadnienia ograniczenia kosztów. Zagadnienie to nie jest proste, bo wiarygodne porównanie parametrów urządzeń obserwacyjnych nie jest łatwe. Producenci urządzeń obserwacyjnych podają w danych katalogowych różne parametry wyznaczane różnymi metodami.

$\mathrm{W}$ ramach prowadzonych prac $\mathrm{w}$ zespole Instytutu Optoelektroniki WAT, w celu właściwej ochrony obiektów infrastruktury krytycznej t.j. porty lotnicze, morskie, jak również rurociągi, wskazano użycie dalekozasięgowych kamer multispektralnych. Jako priorytet, w projektowanych systemach, wskazano prawidłową detekcję obiektu oraz jego wizualizację w różnych warunkach (noc-dzień, mgła, słońce, deszcz). Jednym z urządzeń umożliwiających poprawną wizualizację (rozpoznanie i identyfikację obiektu) jest wyprodukowana przez firmę VIT kamera typu LongView 2. Jest to system składający się z czterech kamer: dziennej kamery szerokokątnej, dziennej kamery wąskokątnej, kamery niskiego poziomu oświetlenia, kamery przeznaczonej do pracy przy dużym zamgleniu. W celu poznania jej cech optoelektronicznych, właściwych do proponowanych zastosowań, na stanowiskach pomiarowych IOE WAT wykonano szereg testów. Niniejszy artykuł prezentuje wybrane z nich.

Wszystkie pomiary parametrów wykonano według własnych procedur pomiarowych opracowanych na podstawie obowiązujących norm [4-7], raportów technicznych NATO [8] oraz fachowej literatury dotyczącej pomiarów parametrów urządzeń obserwacyjnych. Rozszerzoną niepewność pomiaru parametrów wyznaczono na podstawie obowiązujących zaleceń wydanych przez Główny Urząd Miar [9]. Pomiary zostały przeprowadzone przez trzech obserwatorów bez wad wzroku. Końcowe wyniki badań przedstawiono w postaci wartości średniej otrzymanej dla wszystkich obserwatorów biorących udział w badaniach.

\section{Metodyka}

\subsection{Metodyka pomiaru MRTD}

Procedura wyznaczenia charakterystyki minimalnej rozróżnialnej różnicy temperatur MRTD urządzeń termo- wizyjnych jest procedurą opracowaną na podstawie normy NATO STANAG no. 4349. Charakterystyka ta (oś rzędnych $\left[\mathrm{K},{ }^{\circ} \mathrm{C}\right]$, oś odciętych [linii/mrad, $\left.\mathrm{mrad}^{-1}\right]$ ) jest definiowana jako zależność minimalnej różnicy temperatury pasków testu czteropaskowego i temperatury tła, zapewniającej obserwatorowi rozróżnienie między wszystkimi paskami testów a częstością przestrzenną testu.

Obserwator może w trakcie badań optymalizować wartości wzmocnienia toru elektronicznego, jaskrawość ekranu oraz inne mechanizmy regulacji w ramach ograniczeń istniejących w realnych warunkach pracy, a czas obserwacji nie jest ograniczony.

Badania przeprowadza się najpierw dla dodatniej, a następnie ujemnej różnicy temperatury pasków testu względem temperatury tła. Określa się różnice temperatur, przy których obserwator zaczyna rozróżniać wszystkie paski testu. Końcowe wartości MRTD otrzymane dla pojedynczego obserwatora wyznacza się według wzoru

$$
\operatorname{MRTD}(\gamma)=\frac{\Delta T_{+}(\gamma)-\Delta T_{-}(\gamma)}{2}
$$

gdzie: $\Delta T_{+}(\gamma)$ - wartości MRTD wyznaczone dla dodatniej różnicy temperatury pasków testu i temperatury tła dotyczące momentów, kiedy obserwator zaczyna rozróżniać paski testu, $\Delta T(\gamma)$ - wartości $M R T D$ wyznaczone dla ujemnej różnicy temperatury pasków testu i temperatury tła dotyczące momentów, kiedy obserwator zaczyna rozróżniać paski testu.

\subsection{Metodyka pomiaru $M R C$}

Charakterystyka minimalnego rozróżnialnego kontrastu $M R C$ (oś rzędnych [kontrast], oś odciętych [linii/ mrad, $\left.\operatorname{mrad}^{-1}\right]$ ) jest definiowana jako zależność minimalnego rozróżnialnego kontrastu testu USAF 1951[10], zapewniająca odróżnienie wszystkich pasków testów przez obserwatora od częstości przestrzennej testu.

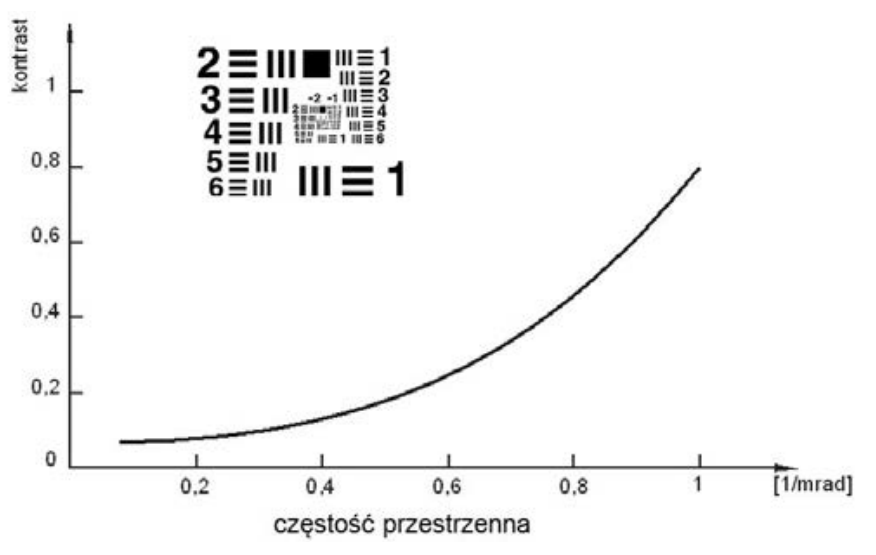

Ryc. 1. Przykładowa charakterystyka $M R C$ oraz test trójpaskowy USAF 1951

Fig. 1. Sample MRC characteristic and USAF 1951 test

Źródło: Opracowanie własne.

Source: Own elaboration.

Rozdzielczość jest definiowana jako maksymalna częstość przestrzenna wzorcowego testu paskowego, przy której paski testu są jeszcze rozróżnialne przez obserwatora. 
Standardowy test trójpaskowy USAF 1951 charakteryzuje się stosunkiem wysokości do szerokości pasków 5:1 (ryc. 1). Odległości między poszczególnymi paskami testów są równe szerokości testów. Obserwator może w trakcie pomiaru charakterystyki $M R C$ regulować natężenie oświetlenia testu w celu uzyskania optymalnej dla niego wartości natężenia.

Badania rozdzielczości urządzenia obserwacyjnego polegają na określeniu grupy i elementu grupy testu USAF 1951 o maksymalnej częstości przestrzennej, przy której wszystkie trzy paski testu są rozróżnialne. Wartości natężenia oświetlenia nie są mierzone w trakcie pomiarów.

\subsection{Metodyka pomiaru $M T F$}

Funkcja przenoszenia modulacji MTF (modulation transfer function) opisuje zniekształcenia obrazu wnoszone przez urządzenie termowizyjne. Jest ona definiowana jako moduł z unormowanej do jedności, dla zerowej częstości przestrzennej, transformaty Fouriera z rozkładu luminancji w obrazie punktowego źródła promieniowania.

Funkcja MTF zawiera informację o zależności stosunku amplitudy obrazu testu o sinusoidalnym rozkładzie egzytancji do amplitudy oryginału w funkcji częstości przestrzennej testu. Funkcja MTF jest w ogólnym przypadku funkcją dwuwymiarową. Jednakże w przypadku urządzeń termowizyjnych zwykle wyznacza się dwie jednowymiarowe funkcje $M T F$ : pionową (przekrój pionowy) i poziomą (przekrój poziomy). Pomiar funkcji $M T F$ jest obiektywny, łatwy do zautomatyzowania i nie wymaga dużej ilości czasu. Dodatkową zaletą funkcji MTF jest możliwość jej wyznaczenia zarówno dla poszczególnych bloków, jak i dla całego urządzenia. Ta ostatnia cecha jest szczególnie użyteczna na etapie projektowania nowych urządzeń obserwacyjnych.

W praktyce zgodnie z literaturą $[4,5,11]$ do pomiaru funkcji MTF urządzeń optycznych i optoelektronicznych wykorzystywane są następujące metody pomiaru: metoda fali sinusoidalnej, metoda fali prostokątnej, metoda wąskiej szczeliny, metoda przekoszonej wąskiej szczeliny, metoda ostrza.

Najczęściej stosowaną metodą pomiaru funkcji $M T F$ kamer termowizyjnych jest metoda ostrza. Istnieje kilka jej modyfikacji, ale wszystkie one opierają się na tej samej idei. Pomiar polega na wyznaczeniu funkcji rozmycia ostrza $E S F$ i na jej podstawie wyliczeniu funkcji $M T F$.

Funkcja rozmycia ostrza opisuje zależność rozkładu sygnału obrazu testu ostrzowego od położenia w płaszczyźnie detekcyjnej. Test ostrzowy powinien być umieszczony w taki sposób, aby jego obraz był równoległy do rzędów lub kolumn detektorów w matrycy.

Sposób wyznaczenia $M T F$ na podstawie funkcji rozmycia ostrza przebiega $\mathrm{w}$ trzech etapach. W etapie pierwszym dokonywana jest akwizycja obrazu z testem ostrzowym, na podstawie której wyznaczymy MTF oraz zostaje wyznaczona średnia wartość funkcji rozmycia ostrza $E S F$. W etapie drugim zostaje wyznaczona funkcja rozmycia linii $L S F$. Średnią wartość funkcji rozmycia linii wyznaczamy z zależności:

$$
\operatorname{LSF}_{a v e}(v)=\frac{d E S F_{a v e}(v)}{d v}
$$

gdzie: $E S F_{a v e}(v)$ jest średnią wartością funkcji rozmycia ostrza.

Różniczkowanie powoduje wzrost szumów (tzw. szumy wirtualne), zatem przed tą operacją zmierzoną funkcję rozmycia ostrza aproksymuje się funkcją matematyczną, która jest różniczkowalna $\mathrm{i}$ z dostateczną dokładnością odwzorowuje przebieg funkcji rozmycia ostrza. Dobrą dokładność odwzorowania zapewnia suma trzech funkcji Fermiego:

$$
F(x)=D+\sum_{i=0}^{2} \frac{a_{i}}{\exp \left[\frac{x-b_{i}}{c_{i}}\right]+1}
$$

gdzie: $D, a_{i}, b_{i}, c_{i}$ są wartościami stałymi, obliczonymi na podstawie średnich wartości sygnałów przed i za ostrzem.

Funkcję $M T F$ wyznaczamy na podstawie wyznaczonej funkcji $L S F$ z zależności:

$$
\operatorname{MSF}_{\text {ave }}(v)=F|\operatorname{LSF}(v)|
$$

Akwizycję danych podczas pomiaru MTF należy przeprowadzić w kierunku prostopadłym do obrazu testu. Pomiary te należy wykonywać dla różnych położeń obrazu testu w płaszczyźnie detekcyjnej. Odległość pomiędzy punktami pomiarowymi jest tu rozumiana jako przesunięcie obrazu testu ostrzowego. Minimalny zakres tej zmiany powinien być równy odległości między punktami pomiarowymi, a skok przemieszczenia obrazu testu nie powinien być większy niż jedna dziesiąta odległości pomiędzy punktami pomiarowymi.

\section{Stanowisko pomiarowe}

Pomiary parametrów urządzeń obserwacyjnych zostały wykonane na systemie pomiarowym MST firmy CI-Systems. Stanowisko pomiarowe składa się z: kolimatora podczerwieni, wzorca promieniowania podczerwieni i widzialnego, sterownika wzorców promieniowania, obrotowej tarczy z zestawem testów, tarczy z zestawem filtrów, komputera wraz z kartą pomiarową wideo i specjalistycznym oprogramowaniem (ryc. 2).

Stanowisko pomiarowe powinno zapewnić pomijalny wpływ na wyniki pomiaru następujących czynników: skończonych wymiarów testu, atmosfery, promieniowania otoczenia, niejednorodności rozkładu temperatury na powierzchni testu i tła, zniekształceń geometrycznych i radiometrycznych kolimatora podczerwieni.

Tarcza wraz z zestawem testów jest umieszczona w płaszczyźnie ogniskowej kolimatora podczerwieni. Za testami znajduje się wzorzec promieniowania. W efekcie, 


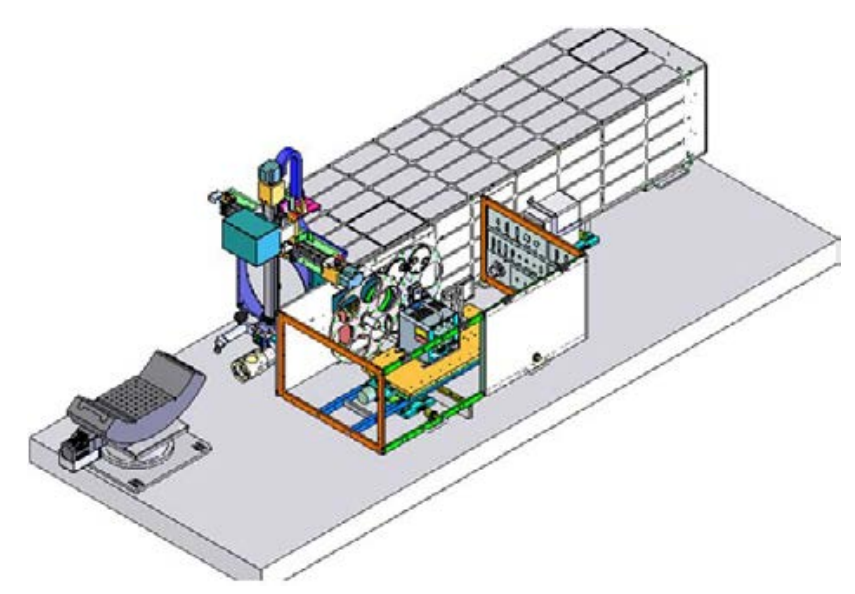

a)

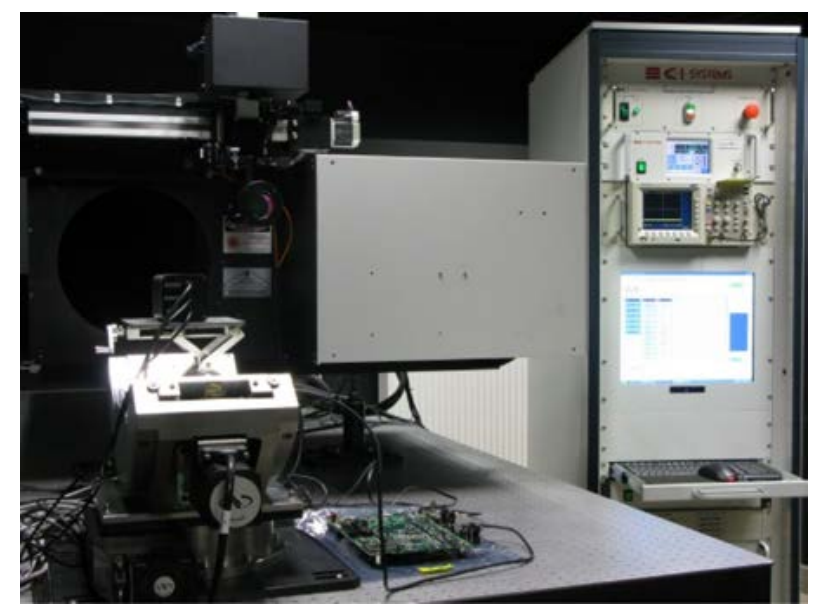

b)

Ryc. 2. Schemat stanowiska do pomiaru parametrów systemów obserwacyjnych

(a), zdjęcie stanowiska do pomiaru parametrów systemów obserwacyjnych (b)

Fig. 2. Observation systems measurements station a) scheme and b) photo

Źródło: Opracowanie własne.

Source: Own elaboration.

w płaszczyźnie ogniskowej kolimatora, powstaje założony rozkład promieniowania podczerwieni lub widzialnego. Regulacja parametrów wzorca promieniowania umożliwia zmianę rozkładu promieniowania.

Zadaniem kolimatora jest zapewnienie wymaganego rozkładu promieniowania w tzw. „nieskończoności optycznej”, czyli w bardzo dalekiej odległości względem badanego urządzenia. Wymóg ten wynika z faktu, że urządzenia obserwacyjne przystosowane są do obserwacji tylko obiektów dalekich. Umieszczenie testów w małej odległości od urządzenia obserwacyjnego spowoduje, że nie będzie ono w stanie właściwie odwzorować rozkładu promieniowania w płaszczyźnie testu. Uzyskane w taki sposób wyniki będą niewiarygodne. Dokładność umieszczenia testów w płaszczyźnie ogniskowej kolimatora nie wpływa na wynik pomiaru [12-15], ponieważ każde urządzenie pomiarowe posiada możliwość skorygowania głębi ostrości widzenia.

Źródło promieniowania wraz z zestawem testów powinno zapewnić uzyskanie wymaganego rozkładu promieniowania z dokładnością niewpływającą na wynik pomiaru. Szczególnie duże wymagania postawione są przed źródłami promieniowania podczerwonego. Muszą one charakteryzować się bardzo dużą jednorodnością rozkładu promieniowania, dokładnością stabilizacji temperatury oraz emisyjnością.

Wykorzystywane testy do pomiarów urządzeń termowizyjnych są wykonywane z metali o wysokiej przewodności cieplnej. Jedna strona testu jest pokrywana powłoką o dużym współczynniku odbicia, (aby zapobiec absorpcji promieniowania otoczenia i wyeliminować wpływ promieniowania otoczenia na temperaturę testów), natomiast druga jest pokrywana powłoką o bardzo wysokiej emisyjności powyżej 0,96 , tak aby test mógł być traktowany jako ciało czarne. Testy transmisyjne stosowane do pomiaru parametrów urządzeń VIS powinny zapewnić dokładność rozkładu promieniowania lepszą niż $1 \%$.

\section{Badania laboratoryjne}

System obserwacyjny LongView 2 składa się z czterech kamer obserwacyjnych pracujących w zakresie promieniowania widzialnego. Kolorowa kamera dzienna umożliwia obserwację obiektów dobrze oświetlonych $(>0,1$ lx) z rozdzielczością 520 linii TV. Kamera nocna (LLTV) umożliwia obserwację obiektów przy oświetleniu 0,00003 luksów (bez konieczności stosowania oświetlaczy IR), w trybie czarno-białym z rozdzielczością 570 linii. Kamera przeciwmgielna (Anty-FOG) umożliwia obserwację obiektów widzianych poprzez: mgłę, dym, mżawkę, deszcz oraz śnieg, w trybie czarno-białym z rozdzielczością 570 linii. Zastosowano w niej 15-dB-ową korektę kontrastu w czasie rzeczywistym, znacznie poprawiającą jakość obrazu (korekcja kontrastu w czasie rzeczywistym jest o wiele efektywniejsza niż stosowanie filtrów korekcyjnych). Dodatkowo zastosowano szerokokątną kamerę wspomagającą nakierowywanie zestawu kamerowego na cel. System obserwacyjny wyposażony jest w dwa wewnętrzne, elektrycznie przełączane, obiektywy stosowane do kamery dziennej, Anty-Fog oraz LLTV. Obiektyw pierwszy charakteryzuje się ogniskową $400 \mathrm{~mm}$ i średnicą $25 \mathrm{~mm}$ oraz powiększeniem optycznym zmienianym w granicach od 6 do 25 razy. Obiektyw drugi charakteryzuje się ogniskową $1050 \mathrm{~mm}$ i średnicą $115 \mathrm{~mm}$ oraz powiększeniem optycznym zmienianym w granicach od 25 do 100 razy.

Dodatkowo w warunkach laboratoryjnych wyznaczone zostały kąty widzenia kamer z zastosowaniem obiektywu $1050 \mathrm{~mm}$ pozwalające na określenie wertykalnego (VFOV) i horyzontalnego (HFOV) pola widzenia kamer przy maksymalnym przybliżeniu optycznym. 
a)

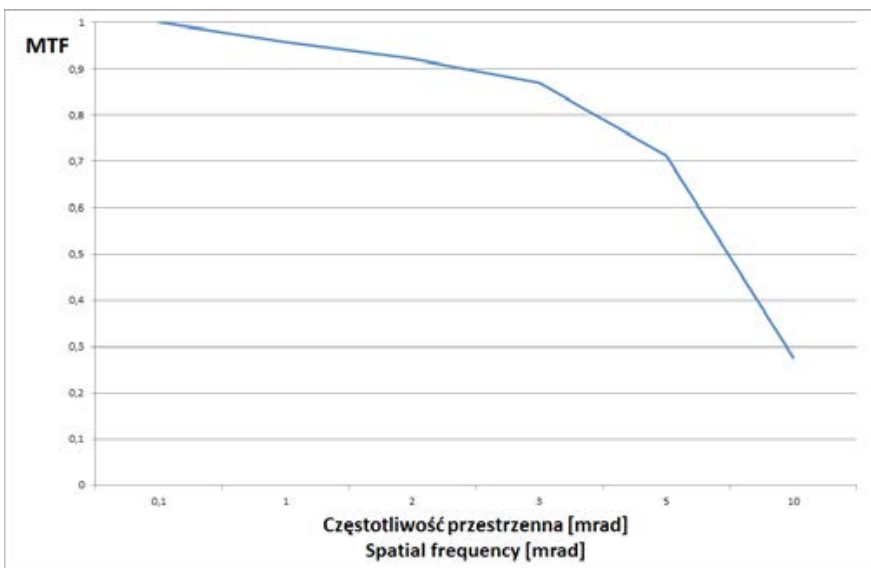

b)

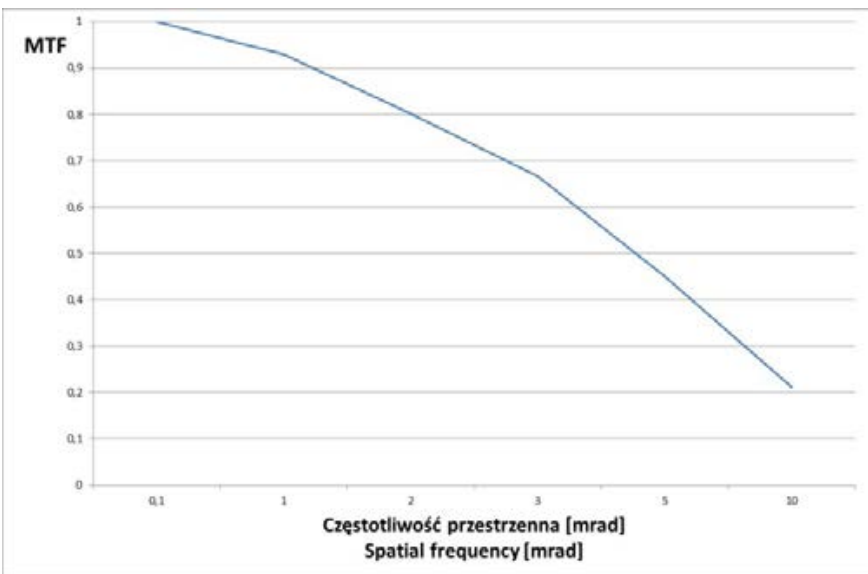

c)

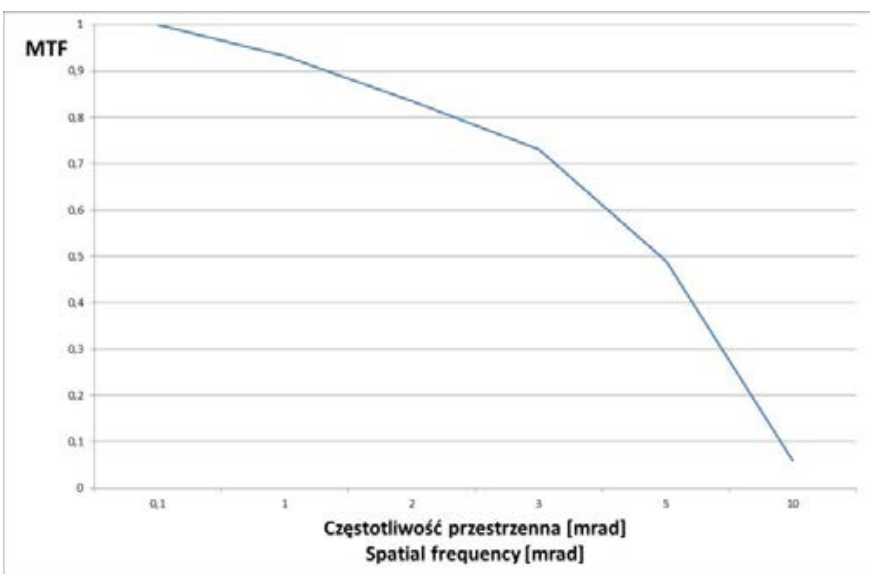

Ryc. 3. Pomiary charakterystyki MTF a) kamera VIS,
b) kamera LLTV, c) kamera FOG

Fig. 3. MTF parameters of LongView2 a)VIS camera,

b) LLTV camera, c) FOG camera

Źródło: Opracowanie własne.

Source: Own elaboration. a)

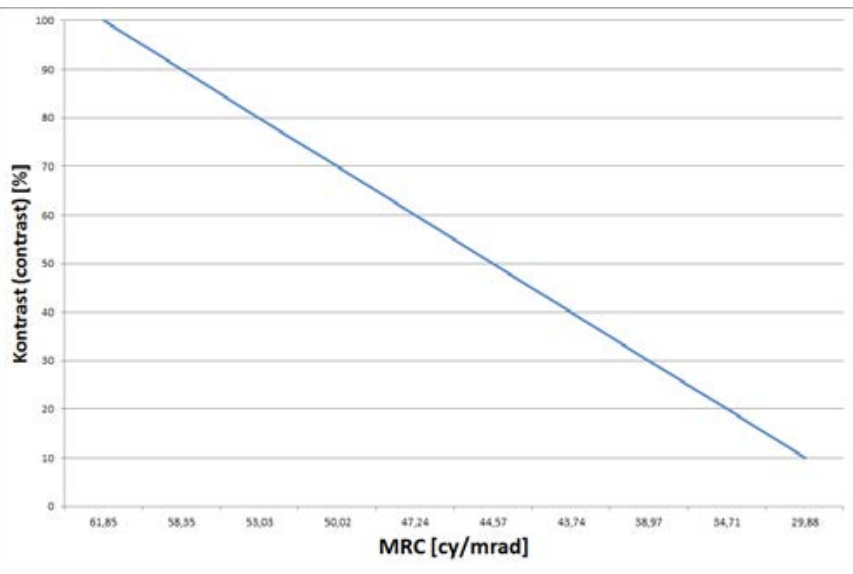

b)

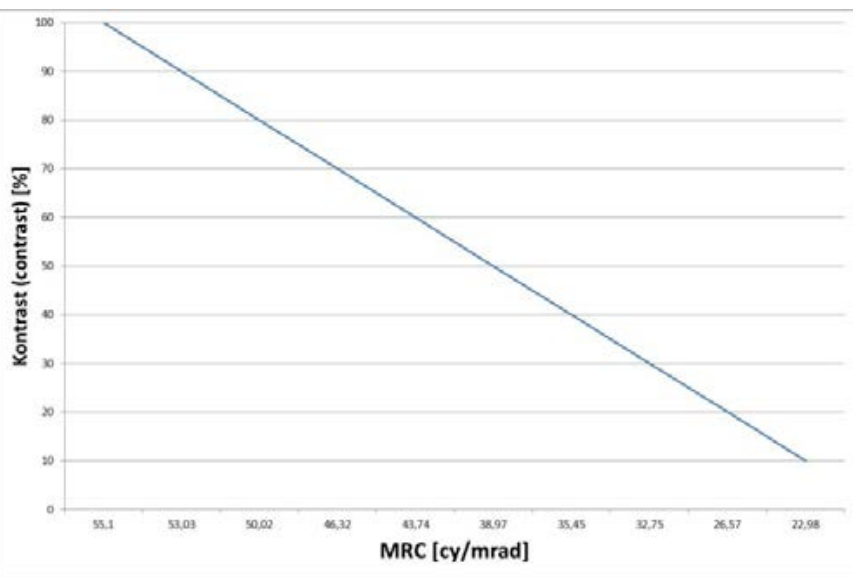

c)

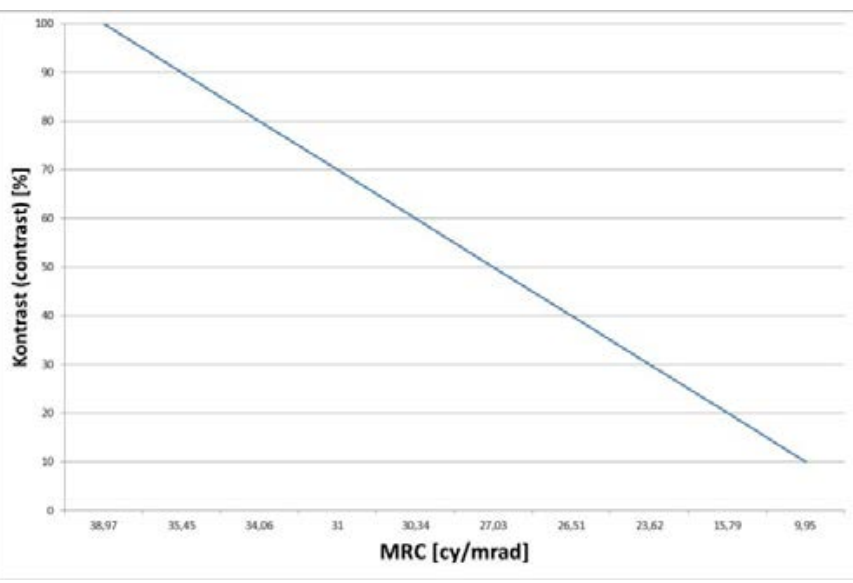

Ryc. 4. Pomiary charakterystyki MRC a) kamera VIS,

b) kamera LLTV, c) kamera FOG

Fig. 4. MRC parameters of LongView 2 a)VIS camera,

b) LLTV camera, c) FOG camera

Źródło: Opracowanie własne.

Source: Own elaboration. 
Pomiar kąta widzenia

Camera field of view

\begin{tabular}{|c|c|c|c|}
\hline Parametr & VIS & LLTV & Anty-FOG \\
\hline HFOV & $1,22^{\circ} \pm 0,08^{\circ}$ & $1,22^{\circ} \pm 0,09^{\circ}$ & $1,20^{\circ} \pm 0,1^{\circ}$ \\
\hline VFOV & $1,40^{\circ} \pm 0,07^{\circ}$ & $1,39^{\circ} \pm 0,08^{\circ}$ & $1,40^{\circ} \pm 0,09^{\circ}$ \\
\hline
\end{tabular}

Źródło: Opracowanie własne.

Source: Own elaboration.

W warunkach laboratoryjnych przebadano system do obserwacji dziennej LongView 2 składający się z czterech kamer: dziennej kamery szerokokątnej, dziennej kamery wąskokątnej, kamery niskiego poziomu oświetlenia, kamery przeznaczonej do pracy przy dużym zamgleniu. Zasięgi wyznaczono na podstawie zmodyfikowanego kryterium Johnsona. Pomiary charakterystyki MRC wykonane zostały zgodnie z normami NATO, tzn. przez trzech doświadczonych obserwatorów bez wad wzroku zgodnie $\mathrm{z}$ procedurą pomiarową akredytowanego Laboratorium Badawczego Instytutu Optoelektroniki WAT „Pomiary parametrów urządzeń termowizyjnych”. Pomiary przeprowadzono przy optymalnym poziomie oświetlenia. Zasięgi kamer wyznaczono dla dobrych warunków pogodowych opisanych zgodnie z następującymi założeniami:

- Cel: człowiek (wymiary 1,8 m x 0,5 m),

- Współczynnik ekstynkcji atmosfery: $0,2 \mathrm{~km}^{-1}$,

- Temperatura otoczenia: $288 \mathrm{~K}$,

- Kontrast celu względem otoczenia: $20 \%$,

- Poziom oświetlenia testu: $30 \mathrm{~lx}$.

Uśrednione wyniki laboratoryjnie wyznaczonych zasięgów poszczególnych kamer systemu LongView 2 przedstawiono w tabeli 2 . Zasięgi te przyjmowane są jako maksymalne i ulegają pogorszeniu wraz z pogarszaniem się warunków atmosferycznych panujących podczas obserwacji.

Zasięgi kamer systemu LongView 2

Tabela 2.

Table 2.

Ranges of cameras in LongView 2 system

\begin{tabular}{|c|c|c|c|}
\hline & VIS & LLTV & Anty-FOG \\
\hline $\begin{array}{c}\text { Wykrycie/ } \\
\text { Detection }\end{array}$ & $10000 \mathrm{~m}$ & $10000 \mathrm{~m}$ & $10000 \mathrm{~m}$ \\
\hline $\begin{array}{c}\text { Rozpoznanie/ } \\
\text { Recognition }\end{array}$ & $7600 \mathrm{~m}$ & $7700 \mathrm{~m}$ & $7750 \mathrm{~m}$ \\
\hline $\begin{array}{c}\text { Identyfikacja/ } \\
\text { Identification }\end{array}$ & $3800 \mathrm{~m}$ & $3900 \mathrm{~m}$ & $4000 \mathrm{~m}$ \\
\hline
\end{tabular}

Źródło: Opracowanie własne.

Source: Own elaboration.

\section{Badania poligonowe}

Przeprowadzone testy polowe miały na celu sprawdzenie sprawności i użyteczności dalekozasięgowego systemu monitorowania LongView 2 do zastosowania w systemach ochrony nabrzeża i portów morskich. Głównym celem testów było sprawdzenie działania poszczególnych kamer w warunkach rzeczywistych, porównanie zasięgów wyznaczonych laboratoryjnie z rzeczywistymi zasięgami w warunkach operacyjnych. Ponadto badania poligonowe pozwoliły na określenie przydatności systemu do detekcji, zobrazowania i oszacowania zagrożenia wynikającego z obecności jednostek pływających znajdujących się w pobliżu portów. Testy zostały przeprowadzone w miejscowości Rewa na obszarze Zatoki Gdańskiej. W chwili testów widoczność wynosiła ok. $40 \mathrm{~km}$, wiatr $2 \mathrm{w}$ skali Beauforta, testy przeprowadzane były całodobowo w celu sprawdzenia działania kamer w różnych warunkach oświetleniowych. Na ryc. 5a pokazano usytuowanie kamery oraz stanowiska pomiarowego podczas testów, a na ryc. 5b naniesione zostały wyznaczone laboratoryjnie zasięgi wykrycia, rozpoznania oraz identyfikacji obiektów.
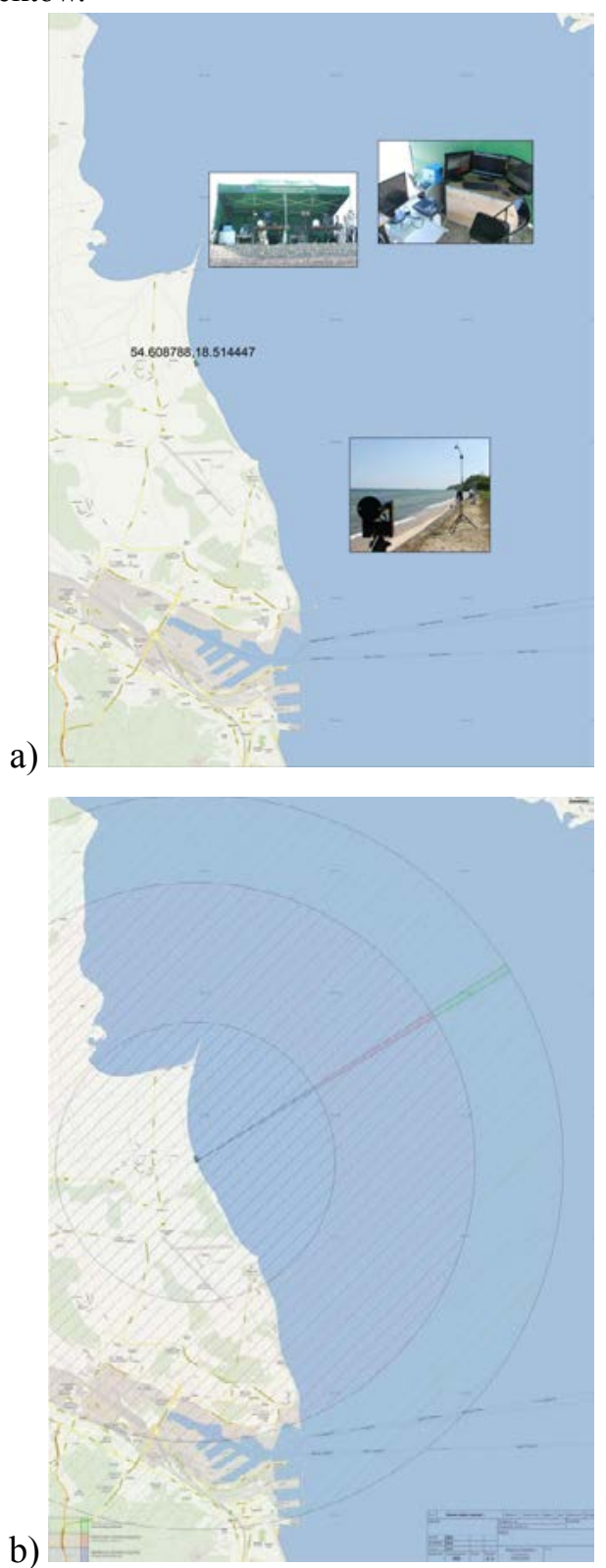

Ryc. 5. a) Schemat położenia i zobrazowania urządzeń demonstratora na testach poligonowych

b) zasięgi kamery dalekozasięgowej demonstratora technologii na testach poligonowych

Fig. 5. a) A scheme of camera location and measurement position during field tests, b) objects detection, recognition and identification ranges designated in field tests

Źródło: Opracowanie własne.

Source: Own elaboration. 
Tabela 3.

Obrazy uzyskane za pomocą kamery Longview 2 o różnych porach dnia i różnych odległościach kutra od kamery

Table 3.

Different cameras objects visualization during field tests field test results

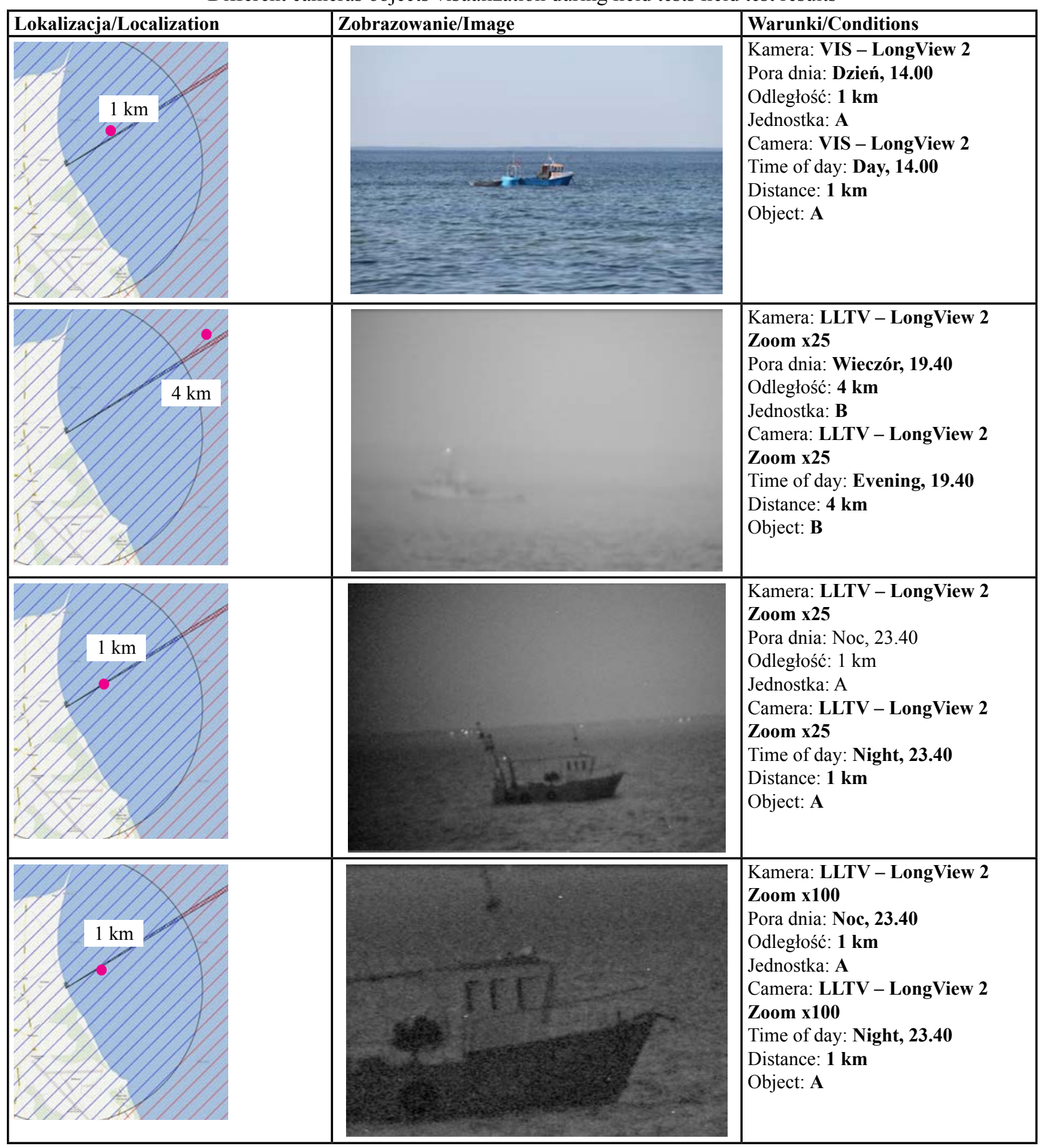

Źródło: Opracowanie własne.

Source: Own elaboration.

Testy wykowywane były z nabrzeża (wysokość ok. 4 m n.p.m.). Jako obiekty testowe zostały wykorzystane jednostki pływające wraz z załogą. Parametry jednostek wykorzystanych do testów to: jednostka A o długości ok. $12 \mathrm{~m}$ i masie ok. 8 ton oraz jednostka B o długości ok. 22 $\mathrm{m}$ i wadze 20 ton. Jednostki testowe znajdowały się w odległościach od 500 do $7000 \mathrm{~m}$ od stanowiska pomiarowego, a załoga symulowała osoby stwarzające zagrożenie. Tabela 3 prezentuje obrazy uzyskane za pomocą systemu
LongView 2 o różnych porach dnia i na różnych odległościach jednostek testowych od kamery. Kolumna pierwsza pokazuje lokalizację zobrazowanego obiektu, kolumna druga zarejestrowany obraz, a kolumna trzecia opisuje typ kamery, czas rejestracji zdjęcia oraz odległość pomiędzy obiektem a kamerą. Przeprowadzone zobrazowania wyzwalane były przez naprowadzenie zespołu kamerowego sygnałem detekcyjnym $\mathrm{z}$ radaru mikrofalowego dla zasięgu do $2 \mathrm{~km}$ oraz ręcznego naprowadzania na odle- 
głościach 2 do $7 \mathrm{~km}$. Testy poligonowe jednoznacznie potwierdziły poprawność zobrazowania obiektów średnich na teoretycznie zapewnianych przez producenta i wyznaczonych laboratoryjnie zasięgach. W trakcie testów porównano laboratoryjnie wyznaczone zasięgi wykrycia, rozpoznania i identyfikacji kamer systemu LongView 2 w warunkach rzeczywistych. Przy dobrych warunkach pogodowych parametry te były nieznacznie niższe, lecz zasięgi były porównywalne $\mathrm{z}$ oczekiwanymi po testach laboratoryjnych i wynosiły odpowiednio: $3500 \mathrm{~m}$ rozpoznanie, $7000 \mathrm{~m}$ rozpoznanie, oraz ok. $10000 \mathrm{~m}$ wykrycie celu. Różnice mogły wynikać z wilgotności powietrza podczas testów, która w bardzo dużym stopniu wpływa na zasięgi kamer systemu LongView 2. Jedną z ciekawszych zaobserwowanych funkcjonalności, wymaganych w systemach ochrony, jest możliwość dokładnego zobrazowania przez kamerę szczegółów na statku, w tym załogi i ewentualnego uzbrojenia $\mathrm{w}$ strefie podejścia do brzegu. Ponadto zaobserwowano, iż w pogorszonych warunkach oświetlenia i przy pojawieniu się mgły system kamerowy spełnia swoje zadania - wizualizuje obiekty na odległościach rzędu kilku kilometrów.

\section{Podsumowanie}

- Przeprowadzone testy laboratoryjne pozwoliły na wyznaczenie teoretycznych zasięgów wykrywania, identyfikacji oraz rozpoznania człowieka przez operatora systemu LongView 2.

- Testy poligonowe zweryfikowały te dane oraz pozwoliły stwierdzić, że możliwe jest stosowanie kamery w dalekozasięgowych systemach obserwacyjnych.

- Kamera daje możliwość wykrycia broni na załodze zbliżających się jednostek.

\section{Wnioski}

W ramach prowadzonych prac opracowano i wykonano szereg testów pomiarowych laboratoryjnych oraz poligonowych systemu obserwacyjnego LongView 2. Badania laboratoryjne wykazały, że za pomocą zestawu kamer system ten pozwala rozpoznać człowieka z odległości 7,6 km. Identyfikacja przedmiotów (w szczególności broni) posiadanych przez niego jest możliwa z odległości 3,8 km. Zasięg detekcji celu ograniczony jest czułością kamery i wynosi ok. $10 \mathrm{~km}$. Przeprowadzone testy poligonowe potwierdziły wyznaczone w laboratoriach zasięgi wykrywania, identyfikacji i rozpoznania celów za pomocą systemu LongView 2 przy dobrych warunkach atmosferycznych. Przeprowadzone testy pokazały możliwości, jakie daje wykorzystanie tej kamery w ochronie zarówno rozległych obiektów morskich, jak i lądowych oraz możliwości wykrycia obiektów zagrażających bezpieczeństwu.

\section{Literatura}

1. Dulski R., Milewski S., Kastek M., Trzaskawka P., Szustakowski M., Ciurapiński W., Życzkowski M., Detection of small surface vessels in near, medium and far infrared spectral bands, Electro-Optical and Infrared Systems: Technology and Applications VIII, Prague, Czech Republic, 2011.

2. Kastek M., Dulski R., Życzkowski M., Szustakowski M., Trzaskawka P., Ciurapinski W., Grelowska G., Gloza I.,
Milewski S., Listewnik K., Multisensor system for the protection of critical infrastructure of a seaport, Unattended Ground, Sea, and Air Sensor Technologies and Applications XIV, Baltimore, Maryland, USA 2012.

3. Szustakowski M., Ciurapinski W., Zyczkowski M., Palka N., Kastek M., Dulski R., Bieszczad G., Sosnowski T., Multispectral system for perimeter protection of stationary and moving objects, Electro-Optical and Infrared Systems: Technology and Applications VI, 74810D, 2011.

4. ISO 15529:1999, Optics and optical instruments: Optical Transfer Function; Measurement of modulation transfer function (MTF) of sampled system, 1999.

5. ISO 9335:1995, Optics and optical instruments: Optical Transfer Function; Principles and procedures of measurement, 1995.

6. NATO STANAG no. 4349, Measurement of the minimum resolvable temperature difference (MRTD) of thermal cameras, 1995.

7. NATO STANAG no. 4351, Measurement of the minimum resolvable contrast (MRC) of image intensifier systems.

8. North Atlantic Treaty Organization, Experimental Assessment Parameters and Procedures for Characterization of Advanced Thermal Imagers, 2003.

9. Wyrażanie niepewności pomiaru. Przewodnik, Główny Urząd Miar, 1999.

10. Resolving Power Target, MIL-STD-150A, Section 5.1.1.7.

11. Glenn D. Boreman, Modulation Transfer Function in Optical and Electro-optical Systems, SPIE Press, 2001.

12. Holst G.C., Testing and Evaluation of infrared Imaging Systems, JCD Publishing Company, 1998.

13. Vollmerhausen R.H., Driggers R.G., Analysis of Sampled Imaging Systems, SPIE Press, 2000.

14. Vollmerhausen R.H., Reago D.A. Jr., Driggers R.G., Analysis and Evaluation of Sampled imaging Systems, SPIE Press, 2010.

15. Ratches J.D., Static Performance Model for Thermal Imaging Systems, “Optical Engineering” Vol. 15 Issue 6, 1976.

prof. dr hab. inż. Mieczysław Szustakowski - kierownik zespołu systemów bezpieczeństwa i analizy zagrożeń w Instytucie Optoelektroniki Wojskowej Akademii Technicznej.

ppłk dr inż. Marek Życzkowski - adiunkt w zakładzie systemów optoelektronicznych Instytutu Optoelektroniki Wojskowej Akademii Technicznej.

mgr inż. Mateusz Karol - doktorant w Instytucie Optoelektroniki Wojskowej Akademii Technicznej.

dr inż. Mariusz Kastek - adiunkt w zakładzie techniki podczerwieni i termowizji Instytutu Optoelektroniki Wojskowej Akademii Technicznej.

ppłk dr inż. Rafał Dulski - adiunkt w zakładzie techniki podczerwieni i termowizji Instytutu Optoelektroniki Wojskowej Akademii Technicznej.

mjr dr inż. Jarosław Bareła - adiunkt w zakładzie techniki podczerwieni i termowizji Instytutu Optoelektroniki Wojskowej Akademii Technicznej.

mgr inż. Piotr Markowski - doktorant w Instytucie Optoelektroniki Wojskowej Akademii Technicznej.

dr inż. Marcin Kowalski - pracownik naukowy w Instytucie Optoelektroniki Wojskowej Akademii Technicznej. 